\title{
KOMUNIKACIJA
}

\section{LIETUVOS AUKŠČIAUSIOSIOS \\ TARYBOS-ATKURIAMOJO SEIMO \\ VAIZDINYS 1991 METU RUSIJOS \\ PERIODINĖJE SPAUDOJE}

VikTor Denisenko

Vilniaus universitetas

Vilnius University

Universiteto g. 3, LT-01513 Vilnius

El.paštas viktor.denisenko@yahoo.com

\section{Santrauka}

Straipsnyje nagrinejamas Lietuvos Aukščiausiosios Tarybos vaizdinys 1991 metu Rusijos periodineje spaudoje. Pristatomas tyrimas paremtas triju ịtakingu laikrǎšciu - „Argumenty i fakty“, „Komsomolskaja pravda“ ir "Izvestija“ - publikacijomis. Straipsnyje kalbama apie istorine Lietuvos Aukščiausiosios Tarybos-Atkuriamojo Seimo reikšmę, taip pat pristatoma Rusijos periodines spaudos situacija 1991 metais, aptariama vaizdinio, kaip tyrimo objekto, problematika. Lietuvos Aukščiausiosios Tarybos vaizdinio 1991 metu Rusijos periodineje spaudoje struktūra, atskleista ir vizualizuota šiuo tyrimu, liudija, kad minetas Lietuvos parlamento diskursas turejo kelias esmines išraiškas (temines paradigmas), susijusias su parlamento veikla, parlamento žmonemis (vadovybè, deputatai ir administracijos darbuotojai), parlamento reikšme plettojant tarptautinius santykius ir simboline parlamento reikšme, taip pat su nagrinèjamam laikotarpiui büdingu konflikto rèmu.

Reikšminiai žodžiai: Lietuvos Aukščiausioji Taryba-Atkuriamasis Seimas; Lietuva; Rusija; periodinè spauda; vaizdinys. 


\section{Ivadas}

1991 metai buvo itin reikšmingi naujausioje Lietuvos istorijoje. Mūsų valstybẻ izženge i juos kaip šalis, faktiškai atkūrusi savo nepriklausomybę, tačiau Maskvoje ì Lietuvą vis dar buvo žiūrima kaip ị sudedamąją Sovietų Sąjungos dalį. Šis požiūris pakito tik po Maskvos pučo (1991 m. rugpjūčio 19-21 d.), kai prasidejjo globalus Lietuvos nepriklausomybès pripažinimo procesas. Baigiantis 1991 metams Lietuvos Respublika jau buvo nepriklausoma valstybe tiek de facto, tiek de jure.

Nagrinejjant minėtą laikotarpi, kuris yra pažymėtas tragiškais įvykiais (Sausio 13-oji, Medininkų tragedija) ir konfliktu su imperine (vertinant Sovietų Sąjungą kaip modernią imperiją) metropolija, svarbu atkreipti demesi i tai, kaip ịvykiai Lietuvoje buvo interpretuojami SSRS branduolyje, t. y. Rusijoje. Realizuoti ši siekị leidžia atitinkamo laikotarpio žiniasklaidos tekstų nagrinejjimas. Minètas metodas buvo pasirinktas ir šiame straipsnyje pristatomam tyrimui.

Lietuvos išstojimo iš Sovietų Sąjungos procesą galima interpretuoti kaip skirtingų valdžios atšakų konfliktą. Šiame konflikte dalyvavo sąjunginė vadovybe், kuri nepripažino Lietuvos nepriklausomybès atkūrimo, ir nepriklausomos Lietuvos valdžios organai ${ }^{1}$. Pagrindinis vaidmuo tiek nepriklausomybès atkūrimo procese, tiek igyvendinant šị sprendimą atitenka Lietuvos Aukščiausiajai Tarybai, t. y. Lietuvos parlamentui. $1990 \mathrm{~m}$. vasario mẻnesị išrinkta Lietuvos Aukščiausioji Taryba (tuo metu dar LTSR Aukščiausioji Taryba) prièmè $1990 \mathrm{~m}$. kovo $11 \mathrm{~d}$. aktą dèl Lietuvos nepriklausomos valstybès atkūrimo. 1990-1992 metų Lietuvos Aukščiausioji Taryba ịejo ị Lietuvos istoriją Lietuvos Aukščiausiosios Tarybos-Atkuriamojo Seimo

1991 metais ir pačioje Lietuvoje fiksuojama dvivaldystès situacija. Pavyzdžiui, minètu laikotarpiu respublikos teritorijoje veikè dvi prokuratūros - Lietuvos Respublikos prokuratūra ir Maskvai lojali ir pavaldi LTSR prokuratūra. 
vardu ${ }^{2}$, tačiau šiame straipsnyje, atsižvelgiant $\mathfrak{i}$ aptariamas istorines realijas, plačiau vartojamas Lietuvos Aukščiausiosios Tarybos (LAT) pavadinimas.

1990-1992 metų LAT „laikytina demokratine parlamentine institucija“3. Tačiau 1991 metų laikotarpiu Maskva, kaip Sovietų Sąjungos centras, aktyviai bandẻ kvestionuoti ši faktą ir LAT priimamų sprendimų legitimumą. Šios istorinès situacijos aplinkybės irgi skatina pasižiūrèti, kaip tuometinèje Rusijos periodinèje spaudoje (pasirinkus tris populiarius ir įtakingus laikraščius - „Argumenty i fakty“, „Komsomolskaja pravda“ ir „Izvestija“) buvo pristatoma ir pozicionuojama LAT, arba, kitaip sakant, koks buvo formuojamas Lietuvos Aukščiausiosios Tarybos vaizdinys šiuose periodiniuose spaudos leidiniuose. Tokio pobūdžio tyrimas leidžia atskleisti ir geriau suprasti Rusijos žiniasklaidos erdvèje formuotą požiūrị i Lietuvos parlamentą sudètingų geopolitinių permainų laikotarpiu. Šiandien, kai moderni Rusijos propaganda grị̌zta prie sovietinès 1990-1991 metų ịvykių interpretacijos ${ }^{4}$, svarbu atskleisti, koks požiūris ị pagrindinị politinị Lietuvos Respublikos nepriklausomybès legitimizacijos organą, t. y. parlamentą, vyravo tuometinèje sovietinèje spaudoje.

2 Sprendimą dèl 1990-1992 metų Lietuvos Aukščiausiosios Tarybos pavadinimo „Lietuvos Taryba-Atkuriamasis Seimas“ 1996 m. lapkričio 28 d. prièmé VII Seimas, atsižvelgęs ị tai, kad LAT ,iš tikrujų ịvykdè atkuriamojo Seimo uždavinius“ (Dèl Lietuvos Respublikos Aukščiausiosios Tarybos-Atkuriamojo Seimo. Prieiga per internetą: https://www.e-tar.lt/acc/legalAct.html?documentId=TAR.47977DD4 5C58 [žiūreta $2016 \mathrm{~m}$. liepos $3 \mathrm{~d}$.]).

3 Blažytė-Baužienè, D. Lietuvos parlamentarai 1990-2004 metais. Parlamento studijos. Nr. 2 (2004). Prieiga per internetą: http://www.parlamentostudijos.lt/Nr3/ Istorija_Blazyte.htm [žiūrèta $2015 \mathrm{~m}$. rugsèjo 1 d.].

4 Šis reiškinys yra susijęs su tuo, ką Nerijus Maliukevičius pavadino procesu, susijusiu su „sistemingu sovietinès praeities inkorporavimu i modernios Rusijos identitetą“" (Maliukevičius, N. Rusijos informacijos geopolitikos potencialas ir sklaida Lietuvoje. Vilnius: Vilniaus universiteto leidykla, 2008, p. 135). 


\section{Rusijos periodinè spauda 1991 metais}

1991 metus galima pavadinti lemtingu laikotarpiu Rusijos periodinei spaudai. Praeito amžiaus dešimto dešimtmečio pradžioje Sovietų Sąungoje vyko žiniasklaidos sistemos transformacija. Pertvarkos (rus. перестройка) ir viešumo (rus. гласность) procesai lèmé tam tikrą periodinès spaudos liberalizavimą. Tai buvo reikšmingi pokyčiai, nes iki to momento Rusijos (kaip ir visos Sovietų Sąungos) žiniasklaida politiškai ir ekonomiškai buvo pasitelkta valdžios interesams ${ }^{5}$.

Sovietinè žiniasklaida turèjo ir ypatingų funkcijų, kurių esmė buvo tarnauti valdančiajam režimui. Akcentuojama, kad prieš pertvarkos laikotarpi visa žiniasklaida Sovietų Sąjungoje buvo kontroliuojama valdžios per politines ir ekonomines priemones; viena esminių tokios kontrolès priemonių buvo cenzūra ${ }^{6}$.

Tačiau praeito amžiaus dešimto dešimtmečio pradžioje situacija pastebimai keičiasi. Vadinamoji tarybinè žiniasklaidos sistema ima transformuotis, 1990 metais Rusijoje isteigtas pirmas nepriklausomas periodinis leidinys „Nezavisimaja gazeta“. Minèti pokyčių procesai užvaldo ir tradicinę Sovietų Sąungos spaudą. Šiuo laikotarpiu ne tik naujos, bet ir senos žiniasklaidos priemonès pajuto didesnę laisvę, smarkiai išaugo ir bendras pasitikejjimas visuomenès informavimo priemonèmis. Žiniasklaida tapo pagrindiniu informacijos apie politinius pokyčius Sovietų Sąjungoje šaltiniu. Pažymima, kad ypač didelị pasitikèjimą pelnè spausdintinès visuomenès informavimo priemonès - laikraščiai ir žurnalai ${ }^{7}$.

5 Усачева, В. Власть и СМИ в России: как изменились их взаимоотношения. Pro et contra. 2000, № 4, p. 110.

6 Becker, J. Lessons from Russia. A Neo-Authoriatarian Media System. European Journal of Communication. 2004, Nr. 19, p. 154.

7 Гудков, Л., Дубин, Б. Общество телезрителей: массы и массовые коммуникации в России конца 90-х годов. Мониторинг общественного мнения. 2001, № 2, p. 31 . 
Pavyzdžiui, 1989 metais spauda visiškai ar iš dalies pasitikejo apie 80 proc. Rusijos gyventojų ${ }^{8}$. Toks aukštas pasitikèjimo lygis išsilaikè iki 1992 metų pradžios, vèliau jis stipriai smuko (iš esmès dèl spaudos komercializacijos ir greito "geltonejjimo“). Kitaip sakant, 1991 metus dar galima priskirti prie laikotarpio, kai periodinès spaudos ịtaka masinei visuomenès sąmonei buvo labai stipri. Tai aktualizuoja būtent Rusijos periodinès spaudos pasirinkimą tiriant Lietuvos Aukščiausiosios Tarybos-Atkuriamojo Seimo vaizdinį, nes tokios žiniasklaidos priemonès turèjo didžiausią auditorijos pasitikejjimo kreditą ir atitinkamai buvo vertinamos kaip pagrindinis patikimų žinių šaltinis.

Kelis žodžius būtina pasakyti ir apie tyrimui atrinktus periodinès spaudos leidinius - savaitrašti "Argumenty i fakty“ bei dienraščius „Komsomolskaja pravda“ ir „Izvestija“. Visi minėti laikraščiai atitinka kelis esminius kriterijus - jie priskiriami prie kokybiškos (analitinès) spaudos paradigmos. Rusijoje šie leidiniai apibrěžiami kaip visuomeniniai politiniai (rus. общественно-политические издания). Visų triju leidinių šaknys siekia sovietmetị, tačiau nagrinėjamu laikotarpiu (1991 metai) minèti laikraščiai buvo orientuoti ị Viešumo politikos principų realizavimą ir visiškai ar iš dalies atsikratè ankstesnių tiesioginių ryšių su valdžios struktūromis (kurios buvo šių leidinių steigèjos ir valdytojos). Pažymima, kad šie leidiniai taip pat atliko aktyvų ir pastebimą vaidmenį permainų laikotarpiu'

Vèliausiai iš šių leidinių atsiradęs savaitraštis „Argumenty i fakty“10. Pirminè šio leidinio paskirtis - būti pagalbine (metodine) priemone lektoriams ir propagandistams (leidinyje buvo publikuojami statistiniai duomenys, perspausdinamos užsienio spaudos publikacijos, pateikiama įdomių faktų). Nuo 1980 metų „Argumenty i fakty“ tapo

8 Дубин, Б. Медиа постсоветской эпохи: изменение установок, функций, оценок. Вестник общественного мнения. 2005, № 2, p. 7.

9 Бендерский, В., Хмылев, В. История отечественных средств массовой информации. Томск: Издательство ТПУ, 2006, p. 124.

${ }^{10}$ İsteigtas 1978 metais kaip Sovietų Sajungos draugijos ,Znanije“ spaudos organas. 
savaitraščiu, kuris tuo metu buvo platinamas ribotam skaičiui prenumeratorių - laisvoje prekyboje šio leidinio nebuvo ${ }^{11}$. Visuomenei jis pradètas platinti 1983 metais. 1990 metais šis laikraštis pateko i Ginnesso rekordų knygą kaip periodinis leidinys, tuo metu turintis didžiausią tiražą pasaulyje - 33,5 mln. egzempliorių. 1991 metais, nors „Argumenty i fakty“ dar priklausè „Znanije“ draugijai, redakcija iš esmès vykdè nepriklausomą leidybos politiką.

Dienraštis „Komsomolskaja pravda“ sovietmečiu atliko Komjaunimo organizacijos informacinio organo funkciją. Situacija pasikeitè 1990 m. gruodžio 1 d. - nuo šios datos leidinys oficialiai buvo vadinamas sąjunginiu dienraščiu, neliko jo afiliacijos su Komjaunimo organizacija $^{12}$.

1990-1992 metais oficialus „Komsomolskaja pravda“ statusas nèra labai aiškus. Viena vertus, šis laikraštis nominaliai išlaiko santyki su oficialiomis valdžios struktūromis, kita vertus - laikraščio valdymą iš esmès perima jo kolektyvas, įkuriamas komercijos skyrius, kuris turi užtikrinti laikraščio leidybą, ruošiamasi steigti uždarąją akcinę bendrovę, kuriai priklausytų laikraštis ${ }^{13}$.

Minètu laikotarpiu laikraštis „Komsomolskaja pravda“ pozicionuojamas kaip vienas populiariausių dienraščių Sovietų Sąungoje (vieno numerio tiražas siekia kelias dešimtis milijonų egzempliorių $\left.{ }^{14}\right)$. Redakcijos kolektyvas, kuris iš esmès perèmè leidinio valdymą ir vykdè gana nepriklausomą informacinę politiką, tuo metu palaikè Michailo Gorbačiovo paskelbtos Viešumo politikos principus, bandė adaptuoti naujas realijas, išlaikydamas sąsają su laikraščio praeitimi. Tai paaiškina, kodèl redakcijos kolektyvas nepakeitė laikraščio pavadinimo (nors

11 История газеты «Аргументы и фактыл». Prieiga per internetą: http://ria.ru/ spravka/20140311/999046720.html\#ixzz3Ed7Tmrgn [žiūrèta 2015 m. rugsèjo 1 d.].

12 Новикова, А. История «Комсомолки». Prieiga per internetą: http://www.kp.ru/ daily/24007/83729/ [žiūrèta 2015 m. rugsèjo 1 d.].

13 Гольдфарб, С. Учебник по истории «Комсомольской правды»». Prieiga per internetą: http://www.kp.ru/daily/24494.5/649149/ [žiūrèta 2015 m. rugsėjo 1 d.].

14 Ten pat. 
toks klausimas buvo svarstomas), išlaikè jị kaip atpažįstamą, savo vertę turintị prekès ženklą ${ }^{15}$.

Dienraštis „Izvestija“ buvo Sovietų Sąjungos Aukščiausiosios Tarybos informacinis organas. Per ilgą istoriją laikraštis kelis kartus keitè paantraštę. Pavyzdžiui, nuo 1977 iki 1991 metų jo oficialų pavadinimą buvo galima versti kaip „SSRS liaudies deputatų tarybų žinios“ (rus. «Известия Советов народных депутатов СССР»). Dabartinis pavadinimas „Izvestija“ atsirado nuo 1991 m. rugpjūčio mènesio, kai žlugo rugpjūčio $19-21 \mathrm{~d}$. Maskvos pučas ${ }^{16}$.

Nors iš visų atrinktų leidinių „Izvestija“ ilgiausiai atliko oficiozo vaidmenị, šis laikraštis irgi kokybiškai keitèsi pagal laisvos spaudos modelị. 1991 metais redakcijoje kilo ilgalaikis konfliktas tarp vyriausiojo redaktoriaus Nikolajaus Jefimovo ir leidinio žurnalistų, norinčių daugiau kūrybinès ir politinès laisvès. Po 1991 m. rugpjūčio 19-21 d. ivykių Maskvoje redakcijos kolektyvas susirinkime atstatydino N. Jefimovą ir paskyrè vyriausiuoju redaktoriumi Igorị Golembovskị ${ }^{17}$. Nuo tuo laiko „Izvestija“ deklaravo nepriklausomybę nuo valdžios ir jos įtakos redakcijos politikai.

Minètos periodinès spaudos žiniasklaidos priemonès buvo pasirinktos tyrimui dèl kelių esminių priežasčių. Pirmiausia, buvo įvertintas bendras periodinių spaudos leidinių populiarumas tiriamuoju laikotarpiu. Praeito amžiaus dešimto dešimtmečio pradžioje būtent periodinè spauda tapo Sovietų Sąjungoje esmine alternatyva oficiozinei, valdžios kontroliuojamai televizijai. 1989 metų duomenimis, periodine spauda visiškai arba iš dalies pasitikejjo 80 proc. Rusijos Federacijos gyvento$j_{u^{18}}{ }^{18}$ Taip pat pripažìstama, kad būtent tokios spausdintinès visuomenès

15 Ten pat.

${ }^{16}$ Газета «Известия». Справка. Prieiga per internetą: http://ria.ru/ spravka/20110603/371165562.html [žiūrèta 2015 m. rugsèjo 1 d.].

${ }^{17}$ Сергеев, С. Предотвратить катастрофу не удалось. Prieiga per internetą: http://izvestia.ru/news/320628 [žiūrèta 2015 m. rugsèjo $1 \mathrm{~d}$.].

18 Дубин, Б. Медиа постсоветской эпохи: изменения установок, функций, оценок. Вестник общественного мнения. 2005, № 2 (76), p. 1. 
informavimo priemonės kaip „Argumenty i fakty“, „Komsomolskaja pravda“ ir „Izvestija“ atliko aktyvų ir pastebimą vaidmeni permainų, susijusių su Sovietų Sąungos žlugimu, laikotarpiu ${ }^{19}$. Kitaip sakant, pateikdamos ir aiškindamos ano meto įvykius bei aktualijas, šios periodinès žiniasklaidos priemonès darè reikšmingą ịtaką Rusijos visuomenei.

\section{Vaizdinio problematika}

Vienas iš esminių klausimų, susijusių su šiame straipsnyje analizuojama tema, yra tai, kaip suprantamas visuomenès informavimo priemonèse konstruojamas vienos ar kitos institucijos (mūsų atveju - Lietuvos Aukščiausiosios Tarybos) vaizdinys. Kaip jis atsiranda ir kokia jo prigimtis?

Pažymima, kad psichologijos sferoje vaizdinys yra pirmiausia suvokimo priemonè. Alfredas Adleris taip aprašo vaizdinio funkciją žmogaus protinèje veikloje: „Jutimo organų pateikiami išoriniai ịspūdžiai ir dirginimai sužadina signalą smegenyse; kai kuriuos šio signalo pėdsakus galima išsaugoti. Iš šių pẻdsakų formuojasi vaizdinių ir prisiminimų pasaulis. Tačiau suvokimas nèra gryna tikrovès nuotrauka, jị visada kažkiek lemia kiekvieno žmogaus savitumas. “20

Psichologijos moksluose vaizdinys yra siejamas su atkartojimu, pavyzdžiui, vaizdiniai atlieka aktyvų vaidmeni prisiminimų procese, taip pat analizès ir apmąstymo sferoje. Vaclovas Martišius akcentuoja, kad „tai, ką mes atkuriame, vadiname atminties vaizdiniais“21.

Tai leidžia teigti, kad vaizdiniai lemia pasaulio suvokimą ir formuoja atitinkamą santykị su aplinka per žmogaus atmintị, įsivaizdavimus ir įsitikinimus. Tokiu būdu vaizdinị galima susieti su tuo, ką Walteris

${ }^{19}$ Бендерский, В., Хмылев, В. История отечественных средств массовой информации. Томск: Издательство ТПУ, 2006, p. 124.

${ }^{20}$ Adler, A. Žmogaus pažinimas. Vilnius: Vaga, 2008, p. 48.

${ }^{21}$ Martišius, V. Kognityvine psichologija. D. 1, Suvokimas ir atmintis. Kaunas: VDU leidykla, 2006, p. 205. 
Lippmannas savo klasikiniame veikale „Viešoji nuomone“ (orig. „Public Opinion“) pavadino „paveikslu (vaizdu) mūsų galvose“. Apibūdindamas ši reiškinį, W. Lippmannas akcentavo, kad „mes suvokiame kaip realią aplinką tai, ką mes manom esant tikru vaizdu“22. Esminis akcentas šioje sampratoje yra būtent manymas (arba kitaip - ịsivaizdavimas).

Tokių vaizdų, kurie padeda žmogui sąveikauti su aplinka, sukūrimo būtinybę W. Lippmannas grịsdavo teiginiu, kad pasaulis yra pernelyg didelis ir sudètingas, kad žmogus galètų su juo sąveikauti tiesiogiai. Tyrèjo tvirtinimu, tam, kad sąveika būtų įmanoma, žmogui kiekvieną kartą tenka bandyti per turimus suvokimo rèmus perkurti pasaulị i paprastesnę formą ${ }^{23}$.

Tokia prieiga leidžia mums bandyti apibūdinti vaizdinị kaip tam tikrą supaprastintą pasaulio atspindị, konstrukciją, kuri leidžia žmogui plètoti sąveiką su vienokiu ar kitokiu realybès reiškiniu ar objektu.

Kitas šiam straipsniui aktualus klausimas būtų - kokiu būdu galima susieti vaizdinị, kaip žmogaus pasaulio suvokimo objektą, su vaizdiniu, pateikiamu (suformuotu) spaudos tekstuose? Aišku, kad ir šiuo atveju vaizdinị būtina vertinti kaip tokio paties pobūdžio supaprastintą (akcentuojantị tik tam tikrus aspektus) pasaulio atspindị, ar, tiksliau, pasaulio vaizdą, tačiau pirmiausia esantị ne žmogaus galvoje, bet atsižvelgiant $\mathfrak{i}$ šio tyrimo aspektus - pateikiamą tekstuose. Absoliutus tokio vaizdinio tikslas yra atsidurti žmogaus (šiuo atveju - skaitytojo) sąmonèje ir būti joje visapusiškai adaptuotam.

Vaizdinio adaptavimo klausimas lieka už šio darbo ribų. Atsižvelgiant $\mathfrak{i}$ tai straipsnyje visų pirma bus siekta atsakyti $\mathfrak{i}$ klausimą, kokia yra Lietuvos Aukščiausiosios Tarybos-Atkuriamojo Seimo vaizdinio struktūra 1991 metų Rusijos periodinès spaudos publikacijose. Arba, kitaip sakant, kokie esminiai aspektai buvo akcentuojami formuojant supaprastintą LAT (ir jos veiklos) „paveikslą“. Vaizdinio struktūros

${ }^{22}$ Lippmann, W. Public Opinion. New Brunswick \& London: Transaction Publishers, 1998, p. 4.

${ }^{23}$ Ten pat, p. 16. 
analizè turètų leisti atsakyti ị klausimą, koki požiūrị ị pagrindines Lietuvos Respublikos valdžios institucijas tuo metu formavo Rusijos žiniasklaida. Atsakymas ị šị klausimą yra svarbus, nes, viena vertus, leidžia parodyti, kaip LAT 1991 metų laikotarpiu buvo „matoma“ Rusijos visuomenès, o, kita vertus, prognozuoti, kokia šio istorinio naratyvo dalis gali būti panaudota moderniosios Rusijos propagandos šiuo metu.

Pateikiamas tyrimas taip pat remiamas prielaida, kad LAT, kaip esminè nepriklausomybę atkūrusios Lietuvos valdžios institucija, buvo svarbi bendro Lietuvos vaizdinio, formuoto tuometineje Rusijos periodineje spaudoje, dalis. Integralus Lietuvos Aukščiausiosios Tarybos vaizdinys ir jo struktūra leistų kalbèti apie tai, kaip Rusijoje buvo „matomi“ esminiai 1991 metu ivvykiai Lietuvoje, taip pat kaip buvo reaguota $\mathfrak{i}$ Lietuvos pastangas įtvirtinti atkurtą valstybingumą. Kitaip sakant, analizuojamas vaizdinys šiuo atveju vertinamas pirmiausia kaip periodinių spaudos leidinių pozicijos atspindys, dominuojančio žurnalistinio požiūrio vektorius. Per šią prizmę jis ir bus interpretuojamas.

\section{Lietuvos Aukščiausiosios Tarybos vaizdinio tyrimas}

Pristatomo empirinio tyrimo pagrindu tapo 99 tekstai, atrinkti iš 1991 metų periodo trijų populiarių Rusijos laikraščių „Komsomolskaja pravda“, „Izvestija“ ir „Argumenty i fakty“. Tekstų atrankos principas - juose vienaip arba kitaip pristatoma LAT veikla, minimas Lietuvos parlamentas ar su juo susiję asmenys.

Siekiant nustatyti giluminius Lietuvos Aukščiausiosios TarybosAtkuriamojo Seimo vaizdinio elementus, atrinktų tekstų analizei buvo panaudotas kokybinis turinio tyrimo metodas, ji taikant atrinkti ir klasifikuoti esminiai teminiai blokai, susiję su LAT.

Atliktas tyrimas parode, kad galima išskirti keturis teminius blokus, dominavusius tekstuose, kuriuose vienaip arba kitaip buvo rašoma apie Lietuvos Aukščiausiąją Tarybą. Jie yra tokie: 
- parlamento veikla (dėmesys LAT ịstatymų veiklai, priimamiems sprendimams, viešai išreiškiamai pozicijai ir pan.);

- parlamento žmonés (LAT deputatai, vadovybè, administracijos darbuotojai);

- parlamentas ir tarptautiniai santykiai (LAT veiksmai, nukreipti ị santykių su kitomis tarybomis užmezgimą, parlamento pozicijos reikšmė pozicionuojant nepriklausomybę atkūrusią Lietuvą tarptautinèje arenoje ir pan.);

- parlamentas kaip vieta (šis teminis blokas iš esmès yra susijęs su ta simboline LAT reikšme, kurią ji turèjo 1991 metais).

Kaip dar vieną temą, tiesiogiai susijusią su parlamento veiklos teminiu bloku, galima išskirti konfliktą. Tiksliau, tai būtų galima apibūdinti ne kaip atskirą teminį bloką, o kaip žurnalistinị rèmą (angl. frame). Konfliktą kaip vieną iš tradicinių naujienų rèmų išskiria tiek Robertas Entmanas $^{24}$, tiek vèliau ir Maxwellas McCombas ${ }^{25}$.

Minèti penki elementai (keturi teminiai blokai ir vienas teminis blokas / rèmas) sudaro Lietuvos Aukščiausiosios Tarybos vaizdinio Rusijos periodineje spaudoje 1991 metais pagrindą. Atlikus kiekybinị išskirtų teminių blokų tyrimą buvo nustatyta, kad daugiausia dèmesio tirtų laikraščių publikacijose buvo skiriama parlamento žmonèms (žr. 1 diagramą). Šis teminis blokas aplenkè kitus teminius blokus. Kiek mažiau dèmesio (26 proc. tekstų) buvo skiriama tiesioginei parlamento veiklai ir informacijai apie ją. 12 proc. publikacijų demesys buvo sutelktas ị išorinę (t. y. tarptautinę) parlamento veikla. Konflikto teminis blokas / rėmas buvo aptiktas 16 proc. tekstų, o parlamento kaip vietos tema -5 proc. tekstų.

Apžvelkime kiekvieną iš minètų kategorijų atskirai.

${ }^{24}$ Entman, R., Framing U. S. Coverage of International News: Contrast in Narratives of the KAL and Iran Air Incidents. Journal of Communication. 1991, No. 4.

${ }^{25}$ McComb, M. Setting the agenda. The mass media and public opinion. Malden: Blackwell Publishing, 2008. 


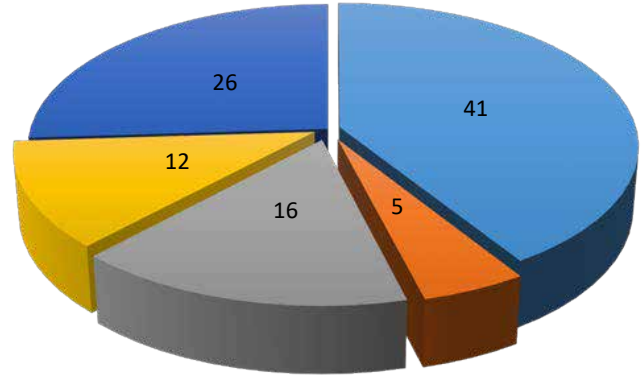

Parlamento žmonès

- Parlamentas kaip vieta

Konfliktas

Parlamentas ir tarptautiniai santykiai

- Parlamento veikla

1 diagrama. Teminiai blokai ir rèmai (proc.)

Parlamento veiklos temini bloką sudaro tekstai, kuriuose minètai temai suteikiami skirtingi (kartais - prieštaringi) vertinimai. Šiuos tekstus imanoma išanalizuoti kaip esmini rodikli pasitelkus tokias kategorijas kaip pozityvus požiūris, negatyvus požiūris ir neutralus požiūris. Šiuo atveju požiūrio orientacijai nustatyti buvo naudojama lingvistikos tyrimuose taikoma konotacijų analizè. Konotacija dažniausiai suprantama kaip žodžio reikšmè, tačiau ji taip pat yra susijusi ir su vertinimo procesu ${ }^{26}$. Atitinkamai ir kiekviena konotacija gali būti priskirta prie vienos iš trijų kategorijų, t. y. pozityvumo, negatyvumo, neutralumo ${ }^{27}$.

Atlikus kokybinę turinio analizę, buvo nustatyta, kad 1991 metų periodo tyrimui pasirinktuose Rusijos periodinès spaudos leidiniuose Lietuvos Aukščiausiosios Tarybos veikla dažniausiai buvo vertinama neutraliai. Atitinkama orientacija aptinkama 52 proc. tekstų (iš 33 šios

${ }^{26}$ Касьянова, Л. Оценочная семантика нового слова. Филология, Искусствоведение. 2008, № 9, p. 46.

${ }^{27}$ Sirtautas, V., Sirtautienė, D. Visuomenès vertybinių prioritetų raiška Lietuvos Respublikos dienraščiuose. Tiltai. 2013, Nr. 3. 
kategorijos publikacijų). Neutralumas šiuo atveju reiškia, kad informacija apie parlamento veiklą buvo pateikiama be pastebimų išankstinių nuostatų, nesuteikiant jai vienokio ar kitokio vertinimo.

Kai kuriais atvejais Lietuvos parlamento veikla Rusijos periodineje spaudoje net susilaukdavo pozityvaus ịvertinimo. Toks vertinimas pastebėtas 12 proc. nagrinėtų tekstų. Minètas pozityvus vertinimas yra ivvairialypio pobūdžio. Pavyzdžiui, tokị vertinimą galima ịžiūrèti Lietuvos valdžią palaikančioje laikraščio „Komsomolskaja praveda“ publikacijoje, kur po tragiškų Sausio 13-osios įvykių pažymima, kad „teisètai išrinkti Lietuvos valdžios organai ir toliau veikia"28. Šiuo atveju pozityvią konotaciją turi akcentuojamas Lietuvos valdžios teisėtumas, nors oficiali Maskva tuo pačiu laikotarpiu bandè kvestionuoti Lietuvos valdžios organų priimamų sprendimų legitimumą.

Pozityvią konotaciją turi ir pranešimai, kuriuose atsispindi parlamentinių jègų pastangos neutralizuoti itampą toje sudètingoje situacijoje, kurioje 1991 metų sausio-rugpjūčio mènesị atsidūrẻ Lietuva. Pavyzdžiui, po tragiškų ịvykių Medininkų muitinès poste vienoje iš publikacijų buvo pranešta: „Sąūdžio“ tarybos atstovai susitiko su Vilniaus OMON’o vadu ir patikino, kad jie neruošia jokių provokacijų. Savo ruožtu majoras patikino, kad ir iš OMON’o pusės jokių provokacijų nebus. Pasiektas konsensusas. “29

Tačiau pozityvus vertinimas iš esmès pasitaiko išimtiniais atvejais. Reikšmingesnę (ir pastebimesnę) Lietuvos Aukščiausiosios Tarybos veiklos vertinimo dalị sudaro publikacijos, kuriose minėta veikla vertinama negatyviai (36 proc. visų šiam teminiam blokui priskirtų publikacijų).

Negatyvus vertinimas formuojamas per informacinị puolimą prieš dominuojančias parlamentines politines jègas. Informacinio smūgio smaigalys pirmiausia yra nukreiptas prieš „Sąjūdị“. Pavyzdžiui, vienoje

${ }^{28}$ Сичка, И. По курсу правый поворот? Комсомольская правда. 1991, № 10, p. 1.

29 Заровский, В. Убийство на литовской таможне: версий становится меньше. Известия. 1991, № 182-183, p. 1. 
iš „Argumenty i fakty“ publikacijų „Sąjūdis“ apibūdinamas kaip „nacionalistų grupuote்"30.

Rusijos periodinèje spaudoje pastebèta ir tiesioginių kaltinimų, nukreiptų prieš „Sąjūdžio“ judèjimą. Pavyzdžiui, galima paminėti Sausio 13-osios ịvykių kontekste oficialios sovietinès propagandos konstruotą mitą, kad prie televizijos bokšto ir Radijo ir televizijos komiteto pastato „savi šaudè ị savus“. Šio mito konstravimo pavyzdį atskleidžia tokia citata: „Sąūuzžio“ atstovai atidengè ugnị. Vienas kareivis buvo nukautas. Kitam kareiviui sprogstanti granata nutraukė koją. Tuomet karo daliniai atidengè ugnị ị viršų, vèliau - $\mathfrak{i}$ užpuolikus. “" ${ }^{31}$ Šiuo atveju sovietinè agresija maskuojama bandant pavaizduoti ją kaip būtinus atsakomuosius veiksmus (t. y. savigyną).

Nesunku pastebėti, kad neigiamas parlamento ar atskiru parlamentinių jègų vertinimas pirmiausia susijęs su konflikto rèmo panaudojimu. Tirtų tekstų analizė parodè, kad tai turi dvilypę prigimtị. Arba, kitaip sakant, galima iš esmès kalbèti apie du skirtingus konflikto rèmus. Viename iš jų (naudojamas dažniausiai - 62 proc. atitinkamų tekstų) parlamentas yra pozicionuojamas kaip konflikto šaltinis. Kitas konflikto rèmas susijęs su vidiniais parlamento konfliktais. Jie Rusijos periodinès spaudos 1991 metų publikacijose sulaukè mažiau dèmesio (38 proc. atitinkamų tekstų).

Parlamento, kaip konflikto šaltinio, rėmas temiškai yra susijęs su politiniu nepriklausomybę atkūrusios Lietuvos ir jos nepriklausomybès nepripažįstančio sąjunginio centro konfliktu. Pavyzdžiui, tokie kaltinimai, nors ir gana atsargiai, skamba tuometinio Sovietų Sąungos Aukščiausiosios Tarybos atstovo Georgijaus Tarazevičiaus interviu laikraščiui „Izvestija“: „Visgi aš nedrịsčiau vadinti Lietuvos parlamento - aukščiausios valdžios respublikoje - avantiūristų susibūrimu. Tačiau, taip - dauguma deputatų nusiteikę radikaliai. Taip, dauguma jų

30 Литва в зеркале иностранной печати. Аргументы и фактыл. 1991, № 3, p. 2-3.

31 Степов, А., Чугаев, С. Вопрос вне повестки дня: ситуация в Литве. Известия. 1991, № 12, p. 1. 
palaiko Lietuvos nepriklausomybės idėją. Čia daug emocijų, kurstomų aistrų, o politinè kova nustelbia gyvenimo realijas." ${ }^{32}$ Tai ne vienintelis atvejis, kai parlamentas ir jo politinès jègos kaltinamos konflikto kurstymu. Pavyzdžiui, tirtų laikraščių puslapiuose yra raginimų LAT „nesiekti paversti dali [respublikos - V. D. pastaba] gyventojų antrarūšiais žmonèmis“33. Lietuvos Aukščiausioji Taryba taip pat buvo kaltinama dèl „nestabilios dvivaldystès“34 situacijos susidarymo (respublikos valdžios ir sąjunginio centro konfliktas).

Lietuvos parlamentas kartais vaizduojamas kaip esminis (ir vienintelis) nestabilumo šaltinis: „Centras turèjo pretekstą šiai akcijai [Sausio 13-oji - V. D. pastaba] - juo tapo bejejgè (rus. беспомощная) politika, kurią parodè Lietuvos parlamentas, demonstruodamas valstybinès išminties stoką, sugebėjęs „pašalinti“ iš politinès arenos Prunskienę ir Brazauską bei vienu ypu papiktinti kariškius, Komunistų partijos narius, darbininkus, rusakalbius gyventojus. “35

Kritinis požiūris i Lietuvos parlamento veiksmus Rusijos periodinejje spaudoje nešvelnejja ir tuomet, kai Lietuva pasiekia nepriklausomybės pripažinimą. Pavyzdžiui, LAT kaltinama destruktyvumu publikacijose, skirtose Lietuvos valdžios struktūrų vykdytam separatistinių nuotaikų malšinimui Vilniaus ir Šalčininkų rajonuose ${ }^{36}$.

Kitas iš aptiktų rèmų, kaip ir minèta, naudojamas fiksuojant vidinius Lietuvos parlamento nesutarimus ir (ar) skandalus. Nemažai dèmesio Rusijos periodinejje spaudoje buvo skirta naujai opozicinei politinei jègai - Lietuvos ateities forumui ir šio forumo reiškiamai kritikai, nukreiptai ị dominuojančias politines jëgas LAT: „Forumo lyderiai

32 Чугуев, С. Было ли в Литве двоевластие? Известия. 1991, № 32. p. 3.

33 Заявление бюро ЦК ВЛКСМ. Комсомольская правда. 1991, № 11, p. 1.

34 Маркарян, К., Заровский, В. Баррикады пока остаются. Комсомольская правда. 1991, № 16, p. 1.

35 Крайний, А., Муратов, Д. «Прощайте, они уже на третьем этаже...». Комсомольская правда. 1991, № 21, р. 2.

36 Pvz. žr.: Лашкевич, Н. В. Трех районах Литвы введено прямое правление. Известия. 1991, № 219, p. 2. 
kritiškai vertina Aukščiausiosios Tarybos veiklą. Jie kaltina parlamentą stokojant aiškios valstybès sukūrimo koncepcijos, deklaratyvios politikos vykdymu ir konfrontacinès taktikos, nukreiptos prieš Sovietų Sąjungą, realizavimu. “37

Panašaus pobūdžio rèmas taikomas ir tekstuose, skirtuose diskusijoms apie nekilnojamojo turto restitucijos ịstatymą. Akcentuojami vidiniai parlamentinių jègų nesutarimai: „Kairioji frakcija paliko posèdžių salę. Jos manymu, įstatymas, nors ir atkurdamas istorinị teisingumą, gali turèti nenumatomų teisinių pasekmių: pažeisti pilietinę vienybę.“38 Taip pat nuosekliai pažymima, kad „balsavimas kojomis“, t. y. paliekant posėdžių salę, tampa „skausminga problema Lietuvos parlamentui“"39.

Su parlamento veiklos klausimu tiesiogiai yra susijęs ir teminis blokas, kuris šiame darbe apibūdintas kaip parlamento žmonès. Pateikiamoje lentelèje (žr. 1 lentelę) fiksuojama, kas iš vadinamųjų parlamento žmonių dažniausiai buvo minimas 1991 metų Rusijos periodinès spaudos publikacijose. Absoliučiu lyderiu pagal paminejjimų skaičių tapo Lietuvos Aukščiausiosios Tarybos pirmininkas (faktiškai - tuometinis Lietuvos vadovas) Vytautas Landsbergis.

1 lentele

\begin{tabular}{|l|c|}
\hline Vytautas Landsbergis & 69 proc. \\
\hline Virgilijus Čepaitis & 9 proc. \\
\hline Algirdas Brazauskas & 8 proc. \\
\hline Česlovas Stankevičius & 6 proc. \\
\hline Vytautas Sinkevičius & 4 proc. \\
\hline Gediminas Kirkilas & 2 proc. \\
\hline Audronius Ažubalis & 2 proc. \\
\hline
\end{tabular}

37 Лашкевич, Н. Оппозиция определилась. Известия. 1991, № 92, p. 2.

38 Лашкевич, Н. Возвращено право собственности. Известия. 1991, № 144, p. 2.

39 Лашкевич, Н. Депутаты голосуют... ногами. Известия. 1991, № 175, p. 2. 
Antroje vietoje atsidūrè parlamento narys Virgilijus Čepaitis, jis dažniausiai minimas dèl skandalo, susijusio su jo praeitimi. Skandalas kilo paaiškejjus, kad V. Čepaitis sovietmečiu bendradarbiavo su KGB. Šiam skandalui Rusijos periodinè spauda skyrè gana daug dème$\mathrm{sio}^{40}$. Minèta tema taip pat tiesiogiai koreliuoja su vidinio parlamentinio konflikto rèmu.

Trečioje vietoje atsidūrè Algirdas Brazauskas, jis traukė Rusijos periodinès spaudos dèmesị kaip opozicijos atstovas, oponuojantis dominuojančioms LAT jègoms. Būtina paminèti, kad A. Brazauskas Rusijos periodineje spaudoje vaizduojamas iš esmès pozityviai (skirtingai nei V. Landsbergis, kurio vaizdinys nèra toks vienareikšmis). A. Brazauskas pozicionuojamas kaip „konstruktyvios opozicijos“41 atstovas.

Kiti parlamento žmonès ir jų paminèjimas Rusijos periodinejje spaudoje nedarè didesnio poveikio Lietuvos Aukščiausiosios Tarybos vaizdinio struktūrai. Grị̌žtant prie asmenų, susijusių su parlamentu, matomumo Rusijos periodinèje spaudoje klausimo būtina plačiau panagrinèti V. Landsbergio pozicionavimą tirtų publikacijų paradigmoje. Juo labiau kad, kaip ir minèta, tuometis Lietuvos Aukščiausiosios Tarybos pirmininkas yra figūra absoliučiai dominuojanti 1991 metų Rusijos periodinès spaudos diskurse, susijusiame su Lietuvos politiniu gyvenimu.

Atlikus tyrimą pastebèta, kad V. Landsbergis nagrinètose publikacijose vertinamas arba neutraliai, arba negatyviai (žr. 2 lentelę). Tekstų proporcija: 3/4 neutralių ir atitinkamai 1/4 negatyvių tekstų. Neutraliuose tekstuose V. Landsbergiui suteikiama tribūna (interviu su LAT pirmininku) arba cituojami jo pasisakymai. Pavyzdžiui: „Valstybių Sandrauga nèra naujoji slavų imperija“, - susitikime su žurnalistais pareiškè Lietuvos parlamento vadovas Vytautas Landsbergis,

40 Pvz., žr.: Лашкеевич, Н. Чепайтис разоблачен. Кто следующий? Известия. 1991, № 294, p. 2.

41 Можаррето, И. На Запад надейся, но сам не плошай. Аргументы и фактыл. 1991, № 24, p. 4. 
atsakydamas ị klausimą apie naują Baltarusijos, Rusijos ir Ukrainos susivienijimą. ${ }^{42}$

2 lentele. Vytauto Landsbergio vertinimas 1991 m. „Argumenty i fakty“, „Komsomolskaja pravda“, „Izvestija“ publikacijose (n=37)

\begin{tabular}{|c|c|}
\hline Vertinimas & Tekstai, vnt. \\
\hline Pozityvus & 0 \\
\hline Negatyvus & 9 \\
\hline Neutralus & 28 \\
\hline
\end{tabular}

Negatyvus V. Landsbergio asmenybès vertinimas labiau susijęs su propagandiniu puolimu, kurị oficialios sąjunginès struktūros (ar asmenys, prijaučiantys jų pozicijoms) vykdè prieš Lietuvą. Pavyzdžiui, „Komsomolskaja pravda“ cituoja tokius Vilniaus OMON’o vado Vladimiro Razvodovo žodžius: "Jūs ir patys žinote, kad rinkimų [ị LAT - V. D. pastaba] rezultatai buvo falsifikuoti. Irodymai? Mes jų turime. Apie ką čia apskritai kalbèti, jeigu Landsbergis yra fašistas, fašisto sūnus." ${ }^{33}$ Šioje citatoje ne tik kvestionuojamas Lietuvos Aukščiausiosios Tarybos legitimumas, bet ir klijuojama „fašisto“ etiketė jos vadovui.

Lygiai taip pat ir oficialiame TASS pranešime dèl Sausio 13-osios ivvkių, kurị paskelbẻ laikraštis „Izvestija“, teigiama, kad „nèra abejonių, jog visos aukos - ant dabartinès Lietuvos vadovybès ir „Sąjūdžio“ sąžinès (rus. жертвы полностью лежат на совести), asmeniné atsakomybè tenka V. Landsbergiui“"44.

42 Лашкевич, Н. Усилия соседей одобрены. Известия. 1991, № 293, p. 2.

43 Маркарян, К., Монахов, А., Мамонтов, В. ОМОН вышел на связь. Связь опять отказала. В Прибалтике снова «тревога»! Комсомольская правда. 1991, № 145, p. 1.

44 ТАСС, Литва. 13 января. Известия. 1991, № 11, p. 1. 
Negatyvaus pobūdžio tekstuose V. Landsbergio asmenybė dažnai demonizuojama. Jam bandoma suversti „asmeninę atsakomybę“ už Lietuvos ir sąjunginio centro konfliktą. Antra vertus, neutralaus pobūdžio tekstuose, kurie, kaip ir minèta, dominuoja, V. Landsbergis vertinamas ir kaip rimtas politinis veikejjas, pripažistamas jo, kaip Lietuvos vadovo, vaidmuo. Jis ir jo pozicija yra nuolatinis Rusijos periodinès spaudos naujienų šaltinis. Dèl šios priežasties galima teigti, kad V. Landsbergio asmenybė ir jos vaizdinys yra tiesiogiai susiję su bendru LAT vaizdiniu ir iš esmès papildo jị.

Rusijos periodinè spauda nagrinejjamu laikotarpiu fiksuoja ir LAT tarpparlamentinès sąveikos užuomazgas. Pirmiausia tai yra susiję su Lietuvos Aukščiausiosios Tarybos ir kitų sovietinių respublikų aukščiausiųjų tarybų santykiais. Pavyzdžiui: „Sausio 13 dieną Pabaltijo ir Rusijos Aukščiausiųų Tarybų vadovai pasirašè bendrą pareiškimą. Jame griežtai smerkiami ginkluotosios prievartos atvejai Pabaltijyje ir neteisètų, ị valdžią pretenduojančių struktūrų veiksmai. “45 Plačiai informuojama ir apie Baltijos Tarybos (Lietuvos, Latvijos ir Estijos tarpparlamentiné asambleja) veiklą ${ }^{46}$.

Taip pat fiksuojami ir LAT siekiai veikti adekvačiu tarptautiniu lygmeniu: „Lietuvos Aukščiausiosios Tarybos deputatai kreipèsi i Jungtinių Tautų organizaciją, siūlydami „pasmerkti TSRS veiksmus, nukreiptus prieš nepriklausomą Lietuvos valstybę. " ${ }^{\prime 7}$

Minètas teminis blokas iš esmès yra neutralaus pobūdžio. Dauguma su šiuo teminiu bloku susijusių publikacijų byloja apie ryžtingas ir nuoseklias Lietuvos pastangas, atkuriant valstybingumą.

Paskutinis iš minètų teminių blokų yra parlamento kaip vietos pozicija. Nors šis teminis blokas yra pats mažiausias ir menkiausiai susijęs su tiesiogine LAT veikla, jis gana reikšmingai papildo bendrą Lietuvos Aukščiausiosios Tarybos vaizdinị Rusijos periodinèje spaudoje. LAT ir

45 Шок. Комсомольская правда. 1991, № 10, p. 1.

46 Литвинова, И. Решение Балтийского совета. Известия. 1991, № 90, p. 2.

47 Лашкевич, Н. Парламент обращается в ООН. Известия. 1991, № 62, р. 2. 
erdvė šalia parlamento pastato pozicionuojama kaip aktyvi politinė erdvė, kurioje irgi sprendžiamas šalies likimas: „Prie parlamento jau trečią dieną visą parą budi dešimtys tūkstančių žmonių. Dainuoja, šoka, verkia, meldžiasi. Nèra jokių neramumų. " ${ }^{48}$

LAT ir erdvè prie parlamento Rusijos periodinès spaudos publikacijose igauna ypatingą simbolinę reikšmę, tampa vyraujančių nuotaikų rodikliu. Pavyzdžiui: „Kiekvieną dieną Vilniuje Nepriklausomybès aikštejje - ant tvorų ir namų sienų, ant Lietuvos parlamentą juosiančių barikadų - atsiranda vis naujų plakatų ir piešinių, kuriuose pateikti kaltinimai Komunistų partijai, žeminama sąjunginè vèliava ir sajunginis herbas (rus. рисунки и плакаты позорящие союзныцй флаг и союзный герб), pakabintos pagiežingos Gorbačiovo, Pugo, Jazovo ir „prie jų prisijungusio“ Vilniaus garnizono vado generolo majoro Uschopčiko karikatūros. Ir ankščiau nebuvo abejonių, o dabar daugiau nei aišku: Lietuva traukiasi [iš Sovietų Sąjungos - V. D. pastaba]. “49

Kitaip sakant, erdvė aplinkui parlamentą nagrinejjamo laikotarpio Rusijos periodinès spaudos publikacijose vertinama kaip politiškai angažuota, "gyvai“ $\mathfrak{x}$ ivvykius bei politinius pokyčius reaguojanti erdvè. Ji tampa ne tik sudètinio LAT vaizdinio, bet ir bendro Lietuvos vaizdinio dalimi.

Atsižvelgiant ì pateiktus duomenis, galima kalbèti ir apie bendrą-schematišką-Lietuvos Aukščiausiosios Tarybos 1991 metų Rusijos periodineje spaudoje vaizdinio struktūrą. Ji pavaizduota 1 paveiksle. Schemoje matyti, kad dominuojantys yra parlamento veiklos (kartu su rèmu) ir parlamento žmoniu diskursai, o parlamento ir tarptautiniu santykiu bei parlamento kaip vietos teminiai blokai papildo bendrą vaizdini, suteikia jam daugiau informacinio vientisumo.

48 Заровский, В. Танки на улицах Вильнюса. Комсомольская правда. 1991, № 9, p. 1.

49 Проценко, А. Какую цель оправдывают «спецсредства». Комсомольская правда. 1991, № 30, р. 2. 


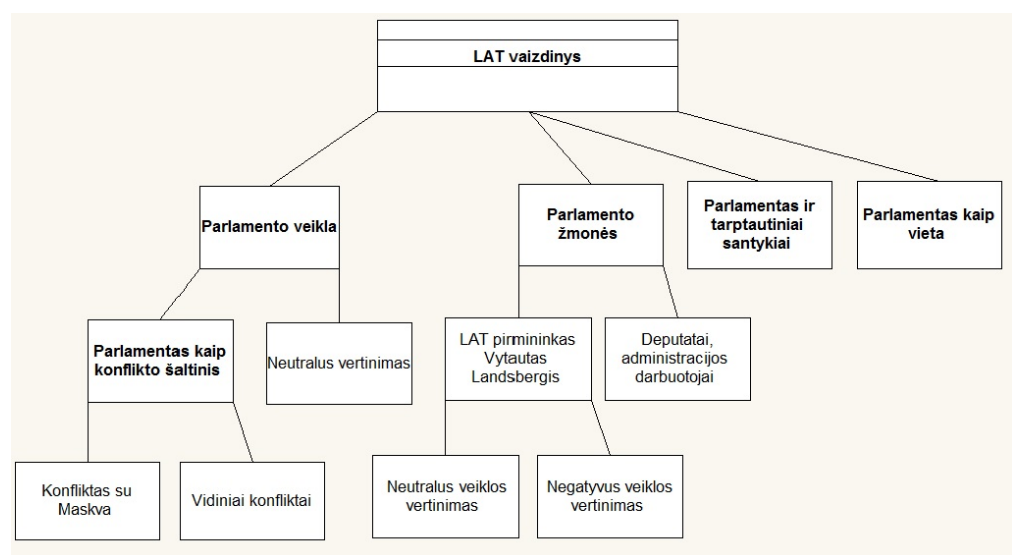

1 paveikslas. Vaizdinio struktūra

\section{Išvados}

1991 metais Rusijoje vyko periodinès spaudos laisvejjimo procesas, kuris lėmė laisvesnị ir ịvairesnị požiūrị i ano meto ịvykius ir atsispindejo minèto periodo publicistiniuose tekstuose. Tiriamojo laikotarpio Rusijos periodinès spaudos skelbtuose straipsniuose iš esmės galima aptikti tiek oficialią Sovietų Sąungos vadovybės poziciją, tiek nepriklausomą ivvykių analizę. Visa tai lemia Lietuvos Aukščiausiosios Tarybos vaizdinio 1991 metų Rusijos periodineje spaudoje sudètingumą ir nevienalytiškumą.

LAT vaizdinio struktūrą sudaro keturios esminès teminès paradigmos, apibrèžtos šiame straipsnyje kaip parlamento veiklos, parlamento žmoniu, parlamento ir tarptautiniu santykiu bei parlamento kaip vietos teminès paradigmos. Vaizdinio struktūroje taip pat aiškiai dominuoja rèmas, kuris pirmiausia yra susijęs su parlamento veiklos temine paradigma ir LAT vadovo V. Landsbergio ịvaizdžiu.

1991 metų Rusijos periodineje spaudoje iš esmès dominuoja neutralus Lietuvos Aukščiausiosios Tarybos vaizdinys. LAT yra matoma 
kaip aukščiausias valdymo organas, kuris geba priimti svarbius sprendimus, veikti sudètingoje situacijoje. Tačiau dali Lietuvos Aukščiausiosios Tarybos vaizdinio sudaro ir negatyvūs elementai, kurie yra susiję su oficialia sovietine propaganda bei bandymu diskredituoti LAT kaip teisètą Lietuvos valdymo organą (pirmiausia, kvestionuojant Lietuvos Aukščiausiosios Tarybos priimamų sprendimų legitimumą).

Situacija keičiasi žlugus Maskvos pučui, kai buvo atveriamas kelias oficialiam Lietuvos nepriklausomybès pripažinimui. LAT legitimumas daugiau nekvestionuojamas, tačiau kritinis požiūris išlieka. Dėmesys nukrypsta nuo aktualumą praradusio LAT ir sąjunginès vadovybès konflikto ị LAT, kaip demokratinès parlamentinès institucijos, veiklą. Šioje tiriamo periodo atkarpoje (po 1991 m. rugpjūčio mėnesio) akcentuojami Lietuvos Aukščiausiosios Tarybos priimami sprendimai (ir jų kritika), taip pat LAT politinio gyvenimo aspektai (vidiniai konfliktai).

Visame periode akcentuojama simbolinè LAT ir jos fizinès aplinkos (Nepriklausomybės aikštės) reikšmè. Rusijos periodinėje spaudoje erdvė prie Lietuvos Aukščiausiosios Tarybos vaizduojama kaip „gyvai“ i politinius procesus ir pokyčius reaguojanti erdvè. Nepriklausomybės aikštė apibūdinama kaip žmonių susibūrimo vieta, kurioje tai demonstruojamas Lietuvos valdžios veiksmų palaikymas, tai protestuojama prieš valdžios sprendimus.

Iš esmès Rusijos periodinèje spaudoje 1991 metais formuotą LAT vaizdinị galima vertinti kaip vieną iš Lietuvos parlamento legitimizacijos ịtvirtinimo priemonių (pirmiausia, Rusijos, kaip imperinès metropolijos, gyventojų akyse). Atsižvelgiant ị tai, galima prognozuoti, kad moderni Rusijos propaganda gali siekti kvestionuoti LAT 1991 metais priimtų sprendimų teisètumą ir legitimumą, t. y. kèsintis ị juridinị Lietuvos Respublikos nepriklausomybės pagrindą, juo labiau kad atitinkami precedentai jau yra fiksuojami ${ }^{50}$.

502015 metų vasarą Rusijos generalinè prokuratūra pagal Dūmos deputatų užklausą pradèjo nagrinèti 1991 metų SSRS valstybès tarybos sprendimo dėl Baltijos šalių nepriklausomybès teisètumą. 
Kalbant apie galimus tolesnius tyrimus, susijusias su šia tema, neabejotinai vertinga būtų išnagrinèti, kaip Lietuvos parlamento vaizdinys Rusijos periodinejje spaudoje (ir plačiau - žiniasklaidoje) keitèsi vèlesniais istoriniais periodais ir kaip šis vaizdinys naudojamas modernios Rusijos propagandos tikslams.

\section{THE IMAGE OF SUPREME COUNCIL OF LITHUANIA (RECONSTITUENT SEIMAS) IN RUSSIAN PERIODICAL PRESS IN 1991}

\section{ViKTOR DENISENKo}

\section{Summary}

Keywords: Supreme Council of Lithuania; Lithuania; Russia; periodical press; image.

The subject of this article is an image of Supreme Council of Lithuania, formed in Russian periodical press in 1991. Presented research was based on publications of three popular and influential Russian newspapers: "Argumenty i fakty", "Komsomolskaja pravda", "Izvestija". The research made in context of historical role of Supreme Council of Lithuania and Russian press situation in 1991. The article also was focused on question of scientific ap- proach to analyze state institution image, formed in media.

The research showed that image of Supreme Council of Lithuania in Russian periodical press in 1991 had manifold structure. As basic elements of image was detected four subject paradigms (Parliament activity, People of Parliament, Parliament and foreign affairs, Parliament as a place) and Conflict frame.

Iteikta $2016 \mathrm{~m}$. liepos $3 \mathrm{~d}$. 